\title{
The Impact of Group Guidance on Graduate Counseling Students' Preference for the Use of Computer-based Technology
}

\author{
Ayoka Mopelola Olusakin \\ Department of Educational Foundations, Faculty of Education. University of Lagos, \\ Akoka-Lagos. Nigeria \\ E-mail: mopeolusakin@yahoo.com
}

KEYWORDS Computer-based technology; group guidance; graduate counseling students; e-mail; video conferencing

\begin{abstract}
Computer-based technology is becoming an integral part of all types of learning and can potentially be used as an important tool in the counseling skills training process and in the counseling practice if the right awareness is created. This study was conducted to examine the impact of group guidance on the graduate counseling students' preference for the use of computer technology. 78 graduate counseling students participated in the study. The participants were randomly assigned into two equal groups, the treatment and the control (delayed treatment) groups. The treatment group participated in the group guidance on the use of computer-based technology while the control group had their own group guidance after the post-test scores were recorded. The results obtained from comparing the pre- and post-test scores of both groups using the Analysis of Covariance and the General Linear Modal statistics showed that those who went through group guidance reported a significant higher preference for the use of computer technology than those in the control group. A significant gender difference was recorded in the analyses indicating that even though both female and male students benefited from the group guidance, male students indicated higher preference for computer technology than the female students.
\end{abstract}

\section{INTRODUCTION}

There is a background story that formed the motivation for this study. A graduate counseling student made a beautiful presentation with the aid of computer technology following three guidance sessions on the use of computer-based technology and the other students gave the presenter a resounding applause and showed interest in knowing how to also make beautiful presentations with the aid of computer technology. This incidence brought to light the need to embark on this study to examine the effect of group guidance on the graduate counseling students' preference for the use of computerbased technology.

\section{Group Guidance}

This is sometimes called 'group therapy' and it involves two or more people meeting together in a group where everyone discusses his/her problem which is common to the whole group. It is an effective way of responding to the various needs of students and is typically used within the classroom setting, to address developmental needs and to implement preventive or remediation programs.

Group guidance addresses specific need and it provides participants with the opportunity to develop and explore common goals and to promote positive changes in an atmosphere of honest sharing and listening. According to Day (2004) group guidance is an efficient and effective way of supporting and helping students deal with problems and issues in educational, career and personal/social areas.

Major objectives of group guidance for students include:

(a) To provide students a means of sharing information on topics such as career information, study skills, and other common challenges.

(b) To help students develop skills for programs such as peer helping, peer tutoring and conflict resolution/management.

(c) To help students develop knowledge and learn personal management and social skills such coping with feelings, dealing with peer pressure, goal-setting, problem-solving, and communication skills

The counselor facilitates the group and encourages people to express their feelings within it. Some people find it very helpful to learn that they are not alone with their challenges.

\section{Computer Technology}

The whole world is becoming a global village through the advent of the computer-based 
technology. So many computer programs are increasingly being used in classroom teaching at all levels. Multimedia presentations are either used in conjunction with or in place of overhead transparencies. Computer-based technology has become an important part of our society. It provides users with applications that can simplify several tasks.

Counseling professionals also use this medium to facilitate their practice. Computerbased technology impacts students in the areas of classroom learning, supervision, and research and distance education. The presence of computer-based technology in so many different aspects of the profession makes it important to more clearly recognize and appreciate its current and potential role.

The rationale for using these computer-based technologies is usually articulated in terms of improving students' learning or preparing students for the world beyond school. A lot of the discussion on classroom uses of technology, however, has focused on how the instructor can incorporate technology into his or her teaching. Not much is known about the students' preference for the use of technology in their courses and the extent to which various uses of technology engage students in ways that affect their learning. Computer technology is not an end in itself, but a means to an end. It provides opportunities that may enhance students' learning, but the mere presence or use of technology in a classroom does not guarantee that learning will be improved. Although the instructor's use of technology sets the stage for learning, it is the students' reaction to, and use of the technology that determines whether the technology would have effect on their learning or not. According to Kozma (1999), technology can be powerful when it is employed as a tool for research, data analysis, and communication. The use of computers is not only for acquiring specific facts and rudimentary skills but it can also be used to bring about a balance between instruction and construction based on the objectives of the lesson.

Thus, students' preference for the use of various technologies can be useful in understanding the relationship between technology and student learning. Computer use in the classroom varies along certain dimensions and different types of technology can be employed. Electronic communication and the use of presentation software during a lecture, for example, provide different contexts for learning. While the former is more consistent with a constructivist approach to learning, the latter is more consistent with a transmission model of teaching and learning. Also each type of technology can be used in different ways. Presentation software, for instance, might be used: a) in a static manner very similar to overhead transparencies; b) to present lecture material in a colorful, visual, and animated manner; or c) to present questions or contrasting points of view in support of a class discussion. The way technology is used by the instructor and the student is as important as the technology itself (Shuell and Farber, 2001).

\section{Related Works}

The use of computer-based technology in the counseling profession is not a totally new concept as computer-based technology have been used as a tool for developing basic counseling interviewing skills (Hummel et al., 1975) and treatment decision-making (Santo and Finkel, 1982).

Kozma (1991) opines that different technologies permit different types of learning experiences, some of which are difficult or impossible to accomplish with traditional forms of instruction. To the extent a particular technology is used in ways that capitalize upon its unique characteristics, there is reason to expect that student learning may be impacted in ways not possible with traditional instructional methods. Not all students respond the same way to different instructional formats and techniques. Various student characteristics, such as their gender and approach to learning, influence students' perceptions of technology and how it is used. According to Shuell (1992) some students prefer lectures to discussions while others feel just the opposite. In their study of field-dependent and field-independent cognitive style and their educational implications, Witkin et al. (1977) report that students also differ with regard to the way they perceive and respond to their environment. Hence Shuell and Farber (2001) submit that potential benefits from using technology in teaching depend on: a) the characteristics of the students; and (b) the type of technology used and the manner in which it is employed. 
Some other studies that have looked at students' use of and attitudes toward technology for learning include: Karayan and Crowe (1997); Sammons (1997); and Cassady (1998). While Sammons (1997) considers the students' preferences for font size, type, and colour, Karayan and Crowe (1997) and Cassady (1998) employ a more in-depth approach, seeking to understand students' reactions to specific forms of technology and how the students perceive technology as helping or hindering their learning.

These two studies found that students believed the use of presentation software enhanced lectures, organized the material and made it more legible, helped students pay attention in class, and served to clarify information. With regard to electronic discussion groups, $52 \%$ of the students surveyed by Karayan and Crowe (1997) indicate they were more likely to answer questions, think more before answering, develop positive relationships with the instructor and peers, and participate in class outside the normal workday with the use of technology. The students also indicated they were more likely to learn the class content with the aid of technology. According to these authors, only $6 \%$ of the students indicated they were less likely to engage in these behaviors when electronic discussion groups are used. Zack (1995) found that students felt the use of email and videoconferencing resulted in the teacher being more accessible and responsive to the students, improved the effectiveness of the instructor and the quality of the course, and enabled the class to develop greater class cohesion.

Brett (1996) surveyed the students' reactions to the use of electronic communication and multimedia software for the purpose of language learning and refers to technology's effect on student motivation and technology's potential for creating more opportunities for students to engage in self-paced learning. In effect, both the way in which technology was utilized and the fact that it was used presented novel situations for the students. They also found the use of technology interesting and motivating. This is much more so where instead of just the use of texts and audio means, electronic communication among peers created new and different learning situations and multimedia software presented a new and different way of learning language.
Researchers (Casey et al., 1994) have concluded that computer-based strategies for improving the supervision experience can be utilized with the appropriate ethical integration of technology. They observe that computer-based technology has become yet another tool supervisors can use to create a more multidimensional approach to their supervision sessions. They are also of the opinion that computer-based technology can be used at both the practicum and internship stage of the counselors' development, especially to facilitate more efficient internship communication when proximity is an issue. Computer-based technologies offer several possibilities for supervisors today.

Each computer-based intervention has its advantages and disadvantages. Supervisors must decide which interventions will most benefit the supervision process and the supervisee. An understanding of the various applications of computer-based supervision and how they might be useful aids supervisors in their deciding what to use. But Clark (1983: 445) gives an analogy of computer-based technology without the students' cooperation as "vehicles that deliver instruction" with no more effect on student learning "than the truck that delivers our groceries causes changes in our nutrition."

\section{Gender Difference in Technology Use}

Some research findings have indicated that male and female students often respond differently to technology and the ways in which it is used (Wiburg, 1995; Shashaani, 1997; Bruner and Bennet, 1998; Butler, 2000). Butler (2000) reported that boys tend to prefer games and random play, while girls seem to prefer computer activities that are goal oriented. Wiburg (1995) noted that men view the computer as a machine that extends their power and so get excited about the computer itself, while women approach the computer more relationally, seeking ways to use it to relate to other people such as sending e-mails. However as noted by the American Association of University Women (1999), there is need for more research regarding the ways that male and female students are using the computer. This study also seeks to find out if there would be gender difference in the influence of group guidance on the graduate students' preference for computer technology. 


\section{Research Hypotheses}

Three hypotheses were tested in this study; Hypothesis 1; There will be no significant difference between the preference for computer technology by participants who were exposed to group guidance and those who were not.

Hypothesis 11; There will there be no significant difference in the pre- and post-test scores of the participants.

Hypothesis 111; Male participants will not benefit more from the group guidance than the female participants.

\section{METHOD}

Participants: Seventy eight graduate counseling students voluntarily participated in the study. 38 of them were female while 40 were male. They were at the first year of a two-year Masters Degree course. All of them had indicated very low preference for computer technology. They were randomly assigned into two groups of Treatment and Delayed Treatment/Control Groups after they had all responded to the questionnaire to collect the pre-test data. Those in treatment group (39 of them; 19 female and 20 male) were exposed to 4 sessions of group guidance as seen in table 1 (see Table1). Those in delayed treatment were not exposed to group guidance until later when the study had been completed. All the participants were given the same questionnaire to respond to before and after the group guidance on the use of technology for the treatment group. The data gathered were used as pre- and post-test scores.

Research Instrument: Students' Preference for Computer Technology Scale (SPCTS) was used. It consists of 15 likert items (apart from the biographical data which was optional except for the gender) that require the participants to indicate any one of the phrases 'Strongly Agree', 'Agree', 'Disagree', or 'Strongly Disagree' in front of each of the statements based on their preference. SPCTS has a construct validity of .81 and test re-test reliability of .77

For scoring, 'Strongly Agree' was allocated 4 points; 'Agree' $=3$ points; 'Disagree' $=2$; 'Agree' $=1$ point. 60 is the maximum while 15 is the minimum score possible for each participant.

Procedure: Following the initial administration of the research instrument to collect data for pretest scores, the participants in the Treatment
Group were further divided into two groups (one group consisted of 20 participants while the other group consisted of 19 participants) for effectiveness of interaction. Each group was exposed to group guidance for four sessions with each session being two hours, once a week. The researcher played the role of the facilitator for the two groups.

The first session was used for introduction and explanation of the group guidance programthe purpose and the process. The participants were asked to discuss what they knew about computer-based technology. They talked of computer typing, word processing, internet e-mail, and web search. They were given an assignment to find out the different components of computer-based technology against the next group guidance session.

The remaining three group guidance sessions were used to discuss the different types of computer-based technology that are useful in enhancing counseling students' training and these include the following: (a) computer-assisted instruction (CAI), (b) the internet's World Wide Web (WWW), (c) Electronic mail, (d) chat rooms/ real-time communication, (e) computer-assisted live supervision (f) cyber supervision, (g) Paperless classroom and (h) Interactive computers / televisions, and satellites. Towards the end of the fourth group guidance session, the research instrument was administered again to collect the post-test data.

Data Analysis: The pre-test and the posttest scores of both the Treatment (Those who participated in group guidance) and the Control Groups were computer-analyzed using the Analysis of Covariance (ANCOVA) and the General Linear Modal statistics. The high mean score was an indication of high preference for computer-based technology.

\section{RESULTS}

The descriptive statistics revealed that the Treatment group had a higher mean of 41.410 with a standard deviation of 9.043 while the Control group had a mean of 20.539 with a standard deviation of 6.065 as seen in table 1 . The comparison of the Treatment and the control groups with tests of between subjects showed a significant difference with $F=169.430$ as seen in table 2.

Also for pre- and post scores, a significant difference was revealed as shown in table 2 where 
Table 1: Descriptive statistics showing the distribution of the Participants and their group means and standard deviation

\begin{tabular}{lllll}
\hline Group & Gender & Mean & S. D. & N \\
\hline Treatment & Female & 36.53 & 6.57 & 19 \\
& Male & 46.05 & 8.73 & 20 \\
\multirow{4}{*}{ Control } & Total & 41.41 & 9.04 & 39 \\
& Female & 20.16 & 4.19 & 19 \\
& Male & 20.90 & 7.52 & 20 \\
Total & Total & 20.54 & 6.06 & 39 \\
& Female & 28.34 & 9.92 & 38 \\
& Male & 33.48 & 15.06 & 40 \\
\hline & Total & 30.97 & 12.99 & 78 \\
\hline
\end{tabular}

Table 2: Analyses of covariance (ANCOVA) tests of between-subjects effects

\begin{tabular}{lrrrrr}
\hline Source & $\begin{array}{l}\text { Sum of } \\
\text { squares }\end{array}$ & $d . f$. & $\begin{array}{l}\text { Mean } \\
\text { squares }\end{array}$ & $F$ & $\begin{array}{l}\text { Signi- } \\
\text { ficance }\end{array}$ \\
\hline $\begin{array}{l}\text { Corrected } \\
\text { model }\end{array}$ & 9389.69 & 4 & 2347.42 & 47.46 & .000 \\
Intercept & 793.25 & 1 & 793.25 & 16.04 & .000 \\
Pretest & 5.75 & 1 & 5.75 & .116 & .734 \\
Group & 8379.25 & 1 & 8379.25 & 169.43 & .000 \\
Gender & 515.99 & 1 & 515.99 & 10.43 & .002 \\
$\begin{array}{l}\text { Group gender } \\
\text { Error }\end{array}$ & 362.41 & 1 & 362.41 & 7.33 & .008 \\
Total & 87834.00 & 78 & & & \\
\hline $\begin{array}{l}\text { Corrected } \\
\text { total }\end{array}$ & 12999.95 & 77 & & & \\
\hline
\end{tabular}

the tests of within subjects corrected model showed $\mathrm{F}=47.465$; and the intercept brought about $\mathrm{F}=16.040$. The pre- and post-test means are 18.731 and 41.280 respectively with a standard error of 1.127 for the treatment group; and pretest $=18.730$, while post-test $=20.536$ with a standard error of 1.127 for the control group as seen in table 3 .

Table 3: Comparison of the means of the post-test scores of the participants exposed to group guidance (Treatment group) and that of the control group dependent variable: Post-test

\begin{tabular}{lllll}
\hline Group & Mean & $\begin{array}{l}\text { Standard } \\
\text { error }\end{array}$ & \multicolumn{2}{c}{$\begin{array}{l}95 \% \text { confidence } \\
\text { interval }\end{array}$} \\
\cline { 3 - 5 } & & & $\begin{array}{l}\text { Lower } \\
\text { bound }\end{array}$ & $\begin{array}{l}\text { Upper } \\
\text { bound }\end{array}$ \\
\hline Treatment & 41.28 (a) & 1.13 & 39.04 & 43.53 \\
Control & 20.54 (a) & 1.13 & 18.29 & 22.78 \\
\hline
\end{tabular}

$\mathrm{a}=$ Covariates appearing in the model are evaluated at the following values: pretest $=18.7308$.

The results revealed a significant difference due to gender. There was an indication that the between and the within groups gender difference was significant at $\mathrm{F}=7.328$ as seen in table 2 .
Table 4: Comparison of the means of female and male participants dependent variable: Post-test

\begin{tabular}{lllll}
\hline Group & Mean & $\begin{array}{l}\text { Standard } \\
\text { error }\end{array}$ & \multicolumn{2}{c}{$\begin{array}{l}\text { 95\% confidence } \\
\text { interval }\end{array}$} \\
\cline { 3 - 5 } & & & $\begin{array}{l}\text { Lower } \\
\text { bound }\end{array}$ & $\begin{array}{l}\text { Upper } \\
\text { bound }\end{array}$ \\
\hline Female & 28.34 (a) & 1.14 & 26.06 & 30.61 \\
Male & 33.48 (a) & 1.11 & 31.27 & 35.70 \\
\hline
\end{tabular}

$\mathrm{a}=$ Covariates appearing in the model are evaluated at the following values: pretest $=18.7308$.

The overall female and male means of 28.335 and 33.482 respectively were recorded for the posttest level with standard error of 1.141 and 1.112 respectively; while the covariate which was the pre-test had a mean of 18.731 as seen in table 4 . The Pairwise comparison of the difference between the mean for the female and the male was also significant. F test that measure the effect of gender based on the linearly independent pairwise comparisons among the estimated marginal means revealed $\mathrm{F}=10.433$ as seen in table 5.

Table 5: Comparison of the sum of squares and the mean square of male and female participants' post-test scores dependent variable: Post-test

\begin{tabular}{lrrlll}
\hline Source & $\begin{array}{l}\text { Sum of } \\
\text { squares }\end{array}$ & $d . f$. & $\begin{array}{l}\text { Mean } \\
\text { squares }\end{array}$ & $F$ & $\begin{array}{l}\text { Signi- } \\
\text { ficance }\end{array}$ \\
\hline Contrast & 515.99 & 1 & 515.99 & 10.43 & .002 \\
Error & 3610.26 & 73 & 49.46 & &
\end{tabular}

The $\mathrm{F}$ tests the effect of gender. This test is based on the linearly independent pairwise comparisons among the estimated marginal means.

\section{DISCUSSION}

The results showed a statistically significant difference in the pre- and post-test means of the participants and specifically indicated that there was a significant difference in the post-test means of the treatment group (those who were exposed to group guidance) compared with the Control group. This implies that group guidance helped to increase the preference of the participants for the use of computer technology. This finding is in agreement with Wampold (2001) who found out that guidance and counseling work. He recorded that the average client who gets guidance is better off than $79 \%$ of similar people who do not receive any. He based this figure on a statistical technique called meta-analysis that allows researcher to put together the results of many studies that compare treatment with no 
treatment. Furthermore, Nicholas and Berman (1983) declared that the gains clients make in therapy are immense.

Computer-based counseling students' learning interventions that were discussed during the group guidance sessions include the following: (a) computer-assisted instruction, (b) the internet's World Wide Web, (c) Electronic mail, (d) chat rooms/real-time communication, (e) computer-assisted live supervision (f) cyber supervision, (g) Paperless classroom and (h) Interactive computers/televisions, and satellites

\section{CONCLUSION}

It is quite evident that technology can make a difference on how and what students learn. With the advancement of computer technology, a wealth of information, communication and interaction available for students or whosoever might want to utilize the opportunities emerged. Computer technology is one piece of the puzzle that can support educational change, but this technology will have little impact without the students' preference for it. Computer technology is most likely to have a positive impact on learning when the students view it as being helpful to them. Of recent, counselor educators have seen the value of computer-based applications in the delivery of counseling supervision.

It is also important to note that computer technology would enhance learning only when students have easy access to the computers in their schools and possibly at homes. Like any other reform effort, the use of computer technology is not just a one-time event but rather it has to be engaged in on a regular basis. Using computers once or twice a week would just have a negligible impact on student learning. Computers make their greatest impact on students' learning when their use is tightly linked to content of the various syllabuses. However, computer technology should be seen as one of the most important tools in a broad-based reform effort to improve students' learning.

While the benefits of computer-based applications are evident, the full potential of this technology has yet to be realized. Computerbased technology will continue to play a significant role in the counseling profession thereby revolutionizing the counseling process. As technological innovations in computer use become more commonplace, both the counseling students and their teachers will continue to find more creative uses to improve the quality of counseling and counselor education Coursol and Lewis, 2000).

Counseling students need to be aware of the many options afforded them through the use of computer-based technology. They must also realize that no one method is problem-free, and the appropriate use of an intervention depends entirely on the needs the have, the practicality of the approach, and the availability of resources and technical support.

Computer-based approaches appear to have many benefits to both supervisee and supervisor; however there could be several problems that need to be addressed. Most importantly is the cost associated with many of these products. Purchasing and installing the equipment needed can be expensive (Hildebrand, 1995). Aside from the cost, many people might not be familiar with the technology and will have to first be trained in how to use the equipment. As with any form of technology, the process is susceptible to electronic technology failure. There is need to spend extra time developing backup plans should the computer-based technology fail to work. This extra planning can in some examples offset the advantages of using a computer-based approach. Computer-based approaches should not be used for their attractiveness and accessibility alone.

\section{Ethical Considerations}

It is pertinent that ethical considerations be reviewed before using any approach in counseling. Computer-based approaches are no different. The British Association for Counseling and Psychotherapy (BACP), the American Counseling Association (ACA)and other counseling associations have developed sets of ethical guidelines for web-based counseling. Grohol (1997) admonishes counselors to consider the potential ethical issues related to the use of technology in the practice of counseling and supervision. Issues that may come up include confidentiality, informed consent, and emergency contact/response issues.

\section{FUTURE TRENDS}

The plan for a comprehensive integration of computer technology needs to occur within the context of the entire school strategic planning 
process. Leadership is a very important factor in the successful integration of computer technology in education. The leadership must have a vision of how computer technology will support student learning and teacher productivity.

In order to empower teachers to teach and students to learn with the aid of computer technology, the university authority would need to plan for ongoing staff development that would take care of large groups.

Furthermore, for technology to have the impact research says it can, more teachers would have to learn more than new computer technology skills; they would need to learn new instructional strategies and new roles. The university authority would need to ensure that teachers have the opportunity and support they need to transform their approach to teaching. The teachers need to teach facts but they also must help students acquire and use the intellectual and workplace skills that are highly in demand in this age of information technology.

Counselor educators need to perform an inventory of training, hardware, and software available within their own organizations. There may be many existing resources of which professionals are simply unaware. Computerbased technology experts should be involved as consultants to share information about successful technology undertakings. And, finally, with the upsurge in technological competence seen in young people, professionals should welcome students' willingness to demonstrate what they know and can do with computer-based technology.

Although counseling programs do not typically include technology training, it is now quite obvious that computer-based technology training need to be incorporated into counselor education programs to achieve the greatest educational impact (Jencius and Paez, 2003).

There is need for more research to be carried out in this area as to the level of preference for computer-based technology of both the counseling students and the counselor educators.

\section{REFERENCES}

American Association of University Women (AAUW) 1999. Gender Gaps: Where Schools Still Fail Our Children. New York: Marlowe.

Bernard, J. M. 1981. "In-service training for clinical supervisors." Professional Psychology, 12: 740-748.
Bradley, L. J. 1989. Counselor Supervision: Principles, Process, and Practice. $2^{\text {nd }}$ Ed. Muncie, IN: Accelerated Development.

Brett, P. 1996. "Using multimedia: An investigation of learner's attitudes." Computer Assisted Learning, 9: 191-212.

Bruner, C. and D. Bennett. 1998. "Technology Perceptions by Gender." Education Digest, 63: 56-58.

Butler, D. 2000. "Gender, Girls, and Computer Technology: What's the Status Now?" The Clearing House, 7: 225-229.

Cassady, J.C. 1998. "Students and instructors' perceptions of the efficacy of computer aided lectures in undergraduate university courses." Journal of Educational Computing Research, 19: 175-189.

Casey, J. A., J. W Bloom and E. R. Moan. 1994. Use of Technology in Counselor Supervision. Greensboro, NC: ERIC Clearinghouse on Counseling and Student Services (Report No. EDO-CG-94-25).

Clark, R. E. 1983. "Reconsidering research on learning from media." Review of Educational Research, 53: 445-459.

Coursol, D. H., and J. Lewis. 2000. "Cyber-supervision: Close encounters in the new millennium." Cybercounseling. Retrieved November 12, 2005 from http: //cybercounseling.uncg.edu/manuscripts/cyber supervision.htm

Day, S. X., 2004. Theory and Design in Counseling and Psychotherapy. Boston, NY: Houghton Mifflin Company.

Fetterman, D. M. 1996. "Video-conferencing on-line: Enhancing communication over the Internet." Educational Researcher, 25: 23-27.

Froehle, T. C. 1984. "Computer-assisted feedback in counseling supervision." Counselor Education and Supervision, 24: 168-175.

Gold, R. S. 1991. Microcomputer Applications in Health Education. Dubuque, IA: William C. Brown Publishers.

Grohol, J. M. 1997. The Insiders Guide to Mental Health Resources Online. New York: Guilford Press.

Haley, J. 1996. Learning and Teaching Therapy. New York: Guilford Press.

Hildebrand, J. E. 1995. Videoconferencing in the business curriculum. Journal of Business and Technical Communication, 9: 228-240.

Hummel, T. J., J. W. Lichtenberg and W. F. Shaffer. 1975. "CLIENT 1: A computer program which simulates client behavior in an initial interview." Journal of Counseling Psychology, 22: 164-169

Jancius, M. and S. Paez. 2003. "Converting counselor ludites: Winning over technology resistant counselors," (Pp. 81-114) in J. W. Bloom, and G. R. Walz, (eds.), Cybercounseling and Cyberlearning: Strategies and Resources for the Millennium. Alexandria, VA: American Counseling Association.

Karayan, S. S. and Crowe, J.A. 1997. "Students' perceptions of electronic discussion groups." T.H.E. Journal, 2(9): 69-71.

Kozma, R.B. 1991. "Learning with media." Review of Educational Research, 61: 179-211.

Klitzke, M. J. and T. W. Lombardo. 1991. A "bug-inthe-eye" can be better than a "bug-in-the-ear." Behavior Modification, 15: 113-117.

Lambert, M. E. 1988. "Computers in counselor education." Counselor Education and Supervision, 28: 100-109. 
Lee, J. L. and C. J. Pulvino. 1988. "Computer competency: A means for learning to be a better counselor." Counselor Education and Supervision, 28: 110-115.

McLean, D. D. and J. M. Hill. 1993. "Supporting internship preparation: A case study in computerbased support." Schole: A Journal of Leisure Studies and Recreation Education, 8: 37-49. EJ 487287.

Mohnsen, B. S. 1995. Using Technology in Physical Education. Champaign, IL: Human Kinetics.

Myrick, R. D. and R. A. Sabella. 1995. "Cyberspace: New place for counselor supervision." Elementary School Guidance and Counseling, 30: 35-44.

Neukrug, E. S. 1991. "Computer-assisted live supervision in counselor skills training." Counselor Education and Supervision, 31: 132-138.

Neu, J. and R. Scarcella. 1991. "World processing in the ESL writing classroom: A survey of student attitudes", (Pp. 169-187) in P. Dunkel (ed.), Computerassisted Language Learning and Testing: Research Issues and Practice. New York: Newbury House Publishers.

Roblyer, M. D. 1997. "Video-conferencing." Learning and Leading with Technology, 24: 58-61.

Sammons, M.C, 1997. "Students assess computer-aided classroom presentations." T.H.E. Journal, 22 (10): $69-71$.

Sandholtz, J. H. 2001. "Learning to teach with technology: A comparison of teacher development programs." Journal of Technology and Teacher Education, 9(3): 349-374

Santo, Y. and A. Finkel. 1982. "CHRIS": A computer simulation of schizophrenia. In B.I. Blum (ed.), Proceedings of the Sixth Annual Symposium On Computer Application in Medical Care (Pp. 737741). Washington, DC: Computer Society Press.

Scherl, C. R. and J. Haley. 2000. "Computer monitor supervision: A clinical note." The American Journal of Family Therapy, 28: 275-282.

Shashaani, L. 1997. "Gender differences in computer attitudes and use among college students." Journal of Educational Computing Research, 16: 37-51.

Shuell, T. J. 1992. "Instructional computing systems for meaningful learning", (Pp.19-54) in M. Jones and P. H. Winne (eds.), Adaptive Learning Environments: Foundations and Frontier. New York: Springer-Verlag.

Shuell, T.J. and S. L. Farber. 2001. "Students' perceptions of technology use in college courses." Journal of Educational Computing Research, 24(2): 119-138.

Spradley, J. P. 1980. Participant's Observation (Orlando, Harcourt Brace Jovanovich College Publishers).

White, R. 1993. How Computers Work. Emeryville, CA: Ziff-Davis Press.

Wiburg, K. 1995. "Gender issues, personal characteristics, and computing," Computing Teacher, 22(4): 7-10.

Witkin, H. A., C. A. Moore, D. R. Goodenough and P. W. Cox. 1977. "Field-dependent and Field-independent cognitive styles and their educational implications." Review of Educational Research, 47: 1-64.

Zack, M. H. 1995. "Using electronic messaging to improve the quality of instruction." Journal of Education for Business, 70, 202-206. 